\title{
NINETEENTH CENTURY URBAN LABOR PRECURSORS OF THE MEXICAN REVOLUTION: THE DEVELOPMENT OF AN IDEOLOGY
}

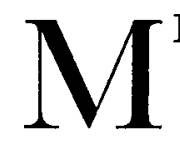

EXICAN industrialization, which began during the second half of the nineteenth century, was paralleled by the appearance of an urban labor movement. Industrialization resulted in a sudden concentration of new workers from the countryside in a few urban areas-especially Mexico City. Living conditions for the new city dwellers were generally intolerable and were compounded by chronic economic and political instability. Crowning the laborer's difficulty were the almost impossible working conditions in the new factories. The working class, virtually in self-defense, began to organize. Because the urban labor movement during the last third of the nineteenth century was a prelude to similar and more famous developments during the violent years of the early twentieth century, analysis of its causes, nature, and significance is essential for understanding an important aspect of the Mexican Revolution. ${ }^{1}$

An open letter of protest, written by the participants in one of Mexico's first large strikes vividly portrayed the situation:

,.. there are workers who receive a weekly salary of sixteen cents and this cannot be denied. The working day extends from 5:15 A.M. to 6:45 P.M. in the summertime, . . in the wintertime from 6:00 A.M. to 6:00 P.M., . . . the foremen only concede five minutes daily to the workers in order for them to eat. ${ }^{2}$

* The author wishes to express his appreciation to the University of North Dakota Faculty Research Committee for summer research grants in 1971 and 1972 which made possible the necessary examination of archives in Mexico City, Amsterdam, and Barcelona.

I Considerable analysis has been made of Emiliano Zapata and Francisco Villa, who were defeated by Alvaro Obregon and his army some of which was drawn from the urban labor movement, especially the Casa del Obrero Mundial. Yet there have been few attempts to evaluate the nature of the Mexican labor movement during the Revolution or its heritage from the nineteenth century. This article, concerned with the nineteenthcentury labor movement, does not encompass the broad scope of nineteenth-century Mexican social history. For such background, see: González y González, Emma Cosío Villegas and Guadalupe Monroy, La Repriblica Restaurada, La Vida Social, and Moisés González Navarro, El Porfiriato, La Vida Social, both in Dani:l Cosío Villegas, ed., La Historia Moderna de México (8 vols., Editorial Hermes, México D. F., n. d.). For a Marxist view of nineteenth-century Mexican socialism, see Gastón García Cantú, El Socialismo en México, Siglo XIX (Ediciones Era, México D. F., 1969).

${ }^{2}$ El Socialista (México D.F.), No. 8, January 23, 1873. 
Intolerable living and working conditions profoundly affected the nature of the emerging labor movement. They encouraged a strong radical-revolutionary bent, while corrupt local and unstable national government increased worker belligerency and distrust of formalized political institutions. This distrust of government was intensified when anarchist ideologues, in the persons of student organizers joined later by Spanish emigres, added their voices to the labor movement.

During the last half of the nineteenth century an anarchist movement of considerable importance developed in Europe. The strongest center of the movement was located in Spain, and it was Spain which contributed the great majority of immigrants to Mexico. Most of the new arrivals had been exposed to anarchist ideas back home; some Catalan anarchist activists were even exiled to what became their adopted homeland in Mexico. These Spanish emigres joined with a group of anarchist Mexican students to contribute the organizational impetus and the ideology for the nineteenth-century Mexican labor movement. ${ }^{8}$

It all began when Plotino C. Rhodakanaty, the intellectual father of Mexican anarchism, emigrated to Mexico in 1861. After attempting but failing to recruit sufficient adherents to undertake an agricultural colony, he accepted a post with a local preparatory school. As a result of his influence, several of his students became adherents to anarchism and in January 1865 they adopted the name El Grupo de Estudiantes Socialistas; later that year they renamed themselves La Social, Sección Internacionalista. The members considered their new organization the Mexican branch of Bakuninism. Although La Social soon broke up and was not reorganized until 1871 , two of its original members were the future leaders of the Mexican labor and anarchist movements-Santiago Villanueva and Francisco Zalacosta. ${ }^{4}$

The first project that these student activists undertook outside of the school involved the organization of urban labor. In October 1864 they revived the defunct first Mexican mutualist organization, composed of

\footnotetext{
${ }^{3}$ For an intensive analysis of the European ideological and organizational influence upon Mexican anarchism and the nineteenth-century labor movement, the differences between urban and rural anarchism, biographical data on the leaders of the movement, and the reactions of orthodox Mexicans see John M. Hart, "Anarchist Thought in Nineteenth Century Mexico," Ph. D. dissertation, the University of California at Los Angeles, December 1970.

4 "Pequeña Biografía de Plotino C. Rhodakanty," La Paz, (Chilpancingo, México), No. 13, March 17, 1873; also José Valadés, Mexico City, to Max Nettlau, April 26, 1924, Nettlau Archive, Internationaal Instituut voor Sociale Geschiedenis, Amsterdam.
} 
workers in the hat-making industry, La Sociedad Particular de Socorros Mútuos, which had failed shortly after its inauguration in $1853 .^{5}$ In November of the same year they reorganized the mutualist association of tailors known as the Sociedad Mútua del Ramo de Sastreria, which had been defunct for ten years. ${ }^{.}$The workers who joined these new groups were initially more conservative than their organizers and inclined toward the more passive type of self-help mutualist groups, devoid of ideological commitments. These associations attempted groupsavings plans to provide life insurance sufficient to cover burial costs and to provide medical care for those in need, but the beginning of a nineteenth century Mexican working class ideology was already present. The students, especially Zalacosta, successfully impressed upon them the more militant ideas of socialism. They argued for mutualist societies which would not only demand immediate pay raises and reduced working hours but, which as "resistance societies would defend themselves against the attacks of the state and capitalism." "

In March 1865 the two newly formed mutualist societies received word from the workers in the textile factories of San Ildefonso, in the neighboring town of Tlalnepantla, and La Colmena that they wanted to "organize in order to protect their interests." The two mutualist societies elected a large delegation, including Zalacosta and Villanueva, to meet with the workers. The resultant conferences produced the Sociedad Mútua del Ramo de Hilados y Tejidos del Valle de México. On March 15, 1865, the delegation from the mutualist organizations joined the newly organized laborers and other employees of the two textile factories in an inauguration dance celebrating the formation of the new mutualist society.

The circumstances behind the workers' decision to organize were indeed harsh. In January 1865 the workers in the San Ildefonso plant had suffered a reduction in their already pitiful pay. Despite this, the tienda de raya had maintained its previous price level and, as usually occurred under these conditions, commanded the greater part of each

- El Obrero Internacional (México D.F.), No. 2, September 7, 1874.

" Valadés, "Sobre los Origenes del Movimiento Obrero en México," La Protesta, (Buenos Aires), June 1927, p. 72. A complete collection of La Protesta, which published many articles pertinent to Mexican anarchism, can be found in the Internationaal Instituut voor Sociale Geschiedenis. See also El Obrero Internacional, No. 2, September 7, 1874; and El Socialista, No. 12, August 25, 1872.

${ }^{7}$ La Internacional (México D.F.), No. 3, July 21, 1878.

${ }^{8}$ Manuel Díaz Ramírez, Apuntes Históricos del Movimiento Obrero y Campesino de México 1844-1880 (Fondo de Cultura Popular, México D. F., 1938), 77. 
worker's salary at the end of the weekly pay period. ${ }^{9}$ About fifty workers had then been laid off in an apparent economy move by the factory management and in addition the owners decided to increase the length of the working day. The date chosen for this action was the first of May 1865. Working hours for women were reset to extend from five in the morning to six forty-five in the evening. For the men the work day was now from five in the morning until seven forty-five in the evening.

On June 10,1865, the workers of the San Ildefonso plant walked off their jobs. The following day the workers at La Colmena followed their example. ${ }^{10}$ Thus began the first strike in Mexican labor history. The workers, perhaps hoping to gain government protection, sent a short and pathetic manifesto describing their plight to the imperial government of Maximiliano. As a direct response a Gendarmería Imperial was created to maintain order in Mexico City and its environs, and a directive was sent to the imperial representative in the Tlalnepantla district ordering him to offer assistance to the proprietor of the San Ildefcnso factory. ${ }^{11}$

On June 19,1865, the government representative, Eulalio Núñez, arrived at the factory with a contingent of about twenty-five armed men. When confronted by an angry mob, he ordered his men to fire. Several workers were wounded, and about twenty-five were arrested. The prisoners, who were taken to the jail at Tepejí del Río, were advised that if they ever returnad to San Ildefonso they would be shot. ${ }^{12}$ The first strike in the long struggle of the Mexican labor movement had ended.

Throughout this episode the organizing efforts of the anarchists had been unimpeded by an imperial government obviously preoccupied with its continuing struggles with the Liberals under Juárez. Thus, the political instability of Mexico that bred contempt in the long run for government had permitted in the short run the organizing success of a handful of anarchist activists. Furthermore, the factory workers of San Ildefonso and $\mathrm{La}$ Colmena were more responsive to the anarchist organizers and were stimulated in their strike efforts because of intolerable working conditions that were typical of the period. Belated government repres-

\footnotetext{
${ }^{9}$ Valadés, "Precursores del Socialismo Antiautoritario en México," La Protesta, May 22,1928, p. 411.

10 Díaz Ramírez, Apuntes, p. 31-32.

${ }^{11}$ Diario del Imperio, (México D. F.), June 19, 1865.

12 "Biografía," La Paz, March 17, 1873.
} 
sion only alienated the workers whom the anarchists later found even more receptive to their ideology and ready to reorganize.

In early 1866 , while Rhodakanaty and Zalacosta were attempting to develop an agrarian commune at Chalco, Villanueva reinstituted a mutualist organization that had expired several years earlier. This association, La Sociedad Artistica Industrial, was critically important to the developing ideology during the next few years; it was dominated by artisans who declared themselves dedicated to the study and discussion of the works of Proudhon and Fourier. Villanueva and the Sociedad membership began to proselytize workers in the Mexico City area and recruit them into mutualist societies. Mexico was now entering its first stage of intensive labor organizing.

Following the fall of Maximilian, Epifanio Romero, the founder of the original Sociedad, returned to Mexico City late in 1867 with other Liberals close to Juárez and attempted to have the organization placed under the aegis of the government. The Sociedad attracted the attention of the Juárez Liberals because, in the absence of a central council of workers, it was the primary source of labor organization and agitation. When Villanueva refused to accede to Romero, a power struggle between the anarchist-led radicals and the moderados began for control of the Sociedad.

Following Romero's initial failure to wrest control of the Sociedad from Villanueva, he and Juan Cano, another supporter of Juárez, founded the Conservatorio Artístico Industrial as a rival group in the late summer of 1867. Juárez was named honorary president of the Conservatorio, and his cabinet aide Francisco Mejía honorary vicepresident. The Conservatorio subsequently received a one-thousand peso donation from one of Juárez's prominent officers, Colonel Miguel Rodríguez. This cash donation was ostensibly for the construction of a new school, but opponents of the Conservatorio considered it evidence of government sponsorship. Their suspicions were reinforced when the Mexican Congress in an obvious show of support for the newly formed Conservatorio, voted it an annual subsidy of $\$ 1,200 .^{13}$

With these successes behind him, Cano defeated Villanueva in the December 1867 organizational election and temporarily gained control of the Sociedad. The rival societies were then united under the original name of La Sociedad Artística Industrial with Cano as president. Finally, the group received as a personal gift from President Juárez the old

${ }^{3}$ Díaz Ramírez, Apuntes, p. 32. 
church of San Pedro y San Pablo as a meeting place. ${ }^{14}$ But other factors were also to play key roles in determining the outcome of Villanueva's early struggle against the pro-Juárez faction led by Cano. In January 1868 Villanueva had succeeded in organizing the textile factory La Fama Montañesa in Tlalpan. This advance was followed up with the formation of the Unión Mútua de Tejedores del Distrito del Tlalpan, which was comprised of newly organized workers at the factories of La Fama Montañesa, Contreras, La Abeja, and Tizapan..$^{15}$

On July 8, 1868, the workers at La Fama Montañesa launched the first successful strike in Mexican history. Their moderate demands consisted mainly of a call for better working conditions and shorter hours for female employees. ${ }^{18}$ The result of this victory was a flurry of organizing activity and enormous prestige for Villanueva, who, restored as president of the Sociedad now had more than enough influence among the lower class workers and artisans to defeat Cano.

Following the successful strike several new associations espousing Proudhonism appeared during the months of July and August 1868. Among them were La Unión de Tejedores de Miraflores, La Asociación Socialista de Tipografos Mexicanos, La Sociedad Mútua del Ramo de Carpintería, and La Unión Mútua de Canteros. In addition, the previously defeated and disbanded mutualist societies in the factories of San Ildefonso and La Colmena were reorganized. Villanueva now found himself surrounded by new associates, all Mexico City artisans who were to be very important in the advancement of cooperativist doctrines. They were Benito Castro, Pedro Ordóñez, Agapito Silva, and Ricardo Velatti. ${ }^{17}$ All except Silva were later active members of the central anarchist group, La Social. ${ }^{18}$

Villanueva planned for a general labor congress to meet in 1868 , but the idea failed because of a lack of funds. He then proposed convening a permanent assembly composed of three delegates from each mutualist society, but the idea again failed for the same reason. Finally, in 1869, he formed a group of labor militants which was named the Círculo

${ }^{14}$ El Hijo del Trabajo (México D.F.), No. 82, February 17, 1878.

${ }_{15}$ Alfonso López Aparicio, El Movimiento Obrero en México (Editorial Jus, México D. F., 1958), 107; and El Socialista, No. 10, 1872.

${ }^{10}$ Díaz Ramírez, Apuntes, p. 33-34; and Lino Medina Salazar, "Albores del Movimiento Obrero en Mexico," Historia y Sociedad, IV, (Mexico D. F., Invierno 1965), p. 60.

17 Díaz Ramírez, Apuntes, p. 33-34; and Medina Salazar, "Albores del Movimiento Obrero en México," Historia y Sociedad, IV, (Invierno, 1965), p. 60.

${ }^{18}$ El Hijo, Nos. 4, May 9, 1876; and 12, July 9, 1876. 
Proletario and was comprised of the above-named cooperativists and Zalacosta, joined by the newcomers José María González, Juan de Mata Rivera, Evarista Meza, and Rafael Pérez de León who attempted to coordinate urban labor organizing activities and disseminate their ideology. Late in 1869 Villanueva's enthusiasm for a central council was rekindled by a newsletter from the International Workingmen's Association circulated by the Geneva Congress in 1866. The three-year delay before it reached Mexico indicates the isolation of that country's socialist movement. On January 10,1870, Villanueva and his associates sent out a call asking for the formation of a "Centro General de los Trabajadores Organizados in order to more effectively defend the interests of labor."

On September 16, 1870, the Centro met for the first time and called itself the Gran Círculo de Obreros de México. The pro-Villanueva faction immediately established its dominance in the organization, and Zalacosta delivered a speech denouncing the Liberals and Cano. The latter, however, was not discouraged; he addressed a letter to Juárez asking for his reaction to the newly formed Círculo. Juárez replied:

Señor don Juan Cano; Esteemed Sir, it is with pleasure that I reply to your letter of yesterday. I wish to convey to you my belief that the artisans should organize their association in whatever manner they may deem convenient in order to achieve perfection in their respective crafts and skills. ${ }^{10}$

Juárez seemed to encourage the artisans to organize in the manner of the Conservatorio. He did not acknowledge in his response the recruitment of common factory workers-a task the Círculo had undertaken.

In spite of the persistent efforts of Cano, the Circulo, stimulated by its anarchist faction, continued its radical program. On March 20,1871, $\mathrm{La}$ Social was again formally reconvened. The membership included Rhodakanaty, Zalacosta, Castro, Velatti, and Ordóñez. In a manifesto they declared: ". . . we want the abolition of all systems of government and liberty for all the manual laborers and intellectuals of the universe." ${ }^{20}$

Villanueva was elected president of the Círculo in early 1871 and began an intense campaign to win new adherents. On July 9, 1871, El Socialista, the first Mexican newspaper that can be described as social-

${ }^{19}$ Quoted by Díaz Ramírez, Apuntes, p. 37-38; see also Juan Cano to Benito Juárez; May 23, 1870, Documento 8164, Archivo Juárez, Gabinete de Manuscritos re la Biblioteca Nacional de México.

20 "Manifesto of La Social," El Socialista, No. 4, May 9, 1876. 
ist, began publication in Mexico City. Several of its writers were members of $\mathrm{La}$ Social and frequently expressed their anarchist ideology. The paper joined the Círculo, became its "official organ," and was duly granted the customary three delegates. La Social also joined the Círculo and sent Velatti, Ordóñez, and Castro as representatives. Most of the other recently formed mutualist organizations in Mexico City and its environs belonged to the Círculo and as a result there was an increased intermingling of anarchists and working men and of their ideas. ${ }^{21}$ Individuals who wished to could join the Círculo, provided they were workers and did not belong to any political party. Employers who were " on good terms with their employees,"-usually artisans who had expanded their trade-were admitted to associate membership. The Círculo was made accessible to almost any sympathizer who cared to join in its activities. ${ }^{22}$

The Círculo's decision not to admit members of political parties expressed a standard anarchist attitude: political boycott and the refusal to recognize the legitimacy of governments larger than the local community or municipio libre. This attitude was given double emphasis by the insistence that workers, while demanding a law guaranteeing the betterment of working conditions, themselves reserved "the right to bring about socialism by means of the social revolution." ${ }^{23}$ The anarchist's insistence that the task of bettering the life of a worker was the worker's own obligation was not only directed to laborers, but was also aimed at parliamentary liberals and their working-class supporters who were regarded by the anarchists and other radicals as likely traitors.

During 1871 the Círculo's first group of elected officers indicated the strength of Villanueva and the radical contingent. They were: president, Villanueva; vice president, Romero; first secretary, Mata Rivera; second secretary, Castro; third secretary, Alejandro Herrera; fourth secretary, Pérez de León; and treasurer, Francisco de Paula González. ${ }^{24}$ Of these men only Romero represented the pro-government group opposed to Villanueva and what constituted an anarchist-radical coalition. Mata Rivera always tried to remain neutral, while Castro and Pérez de León were active members of La Social. ${ }^{25}$

\footnotetext{
${ }^{21}$ El Socialista, Nos. 1, July 9, 1871; and 61, March 1, 1874.

${ }^{22}$ El Socialista, No. 15, September 29, 1872.

${ }^{23} \mathrm{Ibid}$; and José María González, "Nuestra Opinion," El Hijo, No. 54, August 5. 1877; and "Ante Un Cadaver O Ante Una Fiera," El Hijo, No. 88, March 31, 1878.

${ }^{24}$ El Socialista, No. 11, March 16, 1873.

${ }^{23}$ El Hijo, No. 28, December 17, 1876.
} 
Elsewhere in the country, workers were influenced by ideas emanating from Mexico City and began forming mutualist societies and cooperatives. In San Luis Potosí the Asociación Potosina de Obreros was comprised of three new mutualist groups and was in contact with the Círculo in Mexico City. In Toluca a mutualist society was formed and, on November 8, 1871, affiliated with the Círculo. ${ }^{28}$ These events made the spread of anarchist ideology into the hinterlands much easier.

An era in the development of the Mexican labor movement ended with the deaths of President Juárez, on July 18, 1872, and Villanueva, a short time later. Under Juárez, the government had failed to dominate the Círculo; but when Romero replaced Villanueva the situation began to change. The first step took place on September 16, 1872, when the Círculo amended its by-laws to permit the monthly acceptance of $\$ 200.00$ from the new president, Lerdo de Tejada. ${ }^{27}$ By November 1873 , the regular meeting place for the group was the salon of the Sociedad Unionista de Sombreros, an organization led by Cano and Romero. ${ }^{28}$

At the end of the critical year 1872, the opposing forces within the Círculo were clearly defined. One group, greatly influenced by Rhodakanaty, Villanueva, and Zalacosta, was anarchist and revolutionary. Lacking a majority, they continued to exercise considerable political influence upon the membership by preparing manifestos calling for the organization of the working class and describing the proper role of government, and also by the election of La Social members Castro and Pérez de León to the Círculo directorate. In addition, Rhodakanaty, Velatti, and Ordónez, continued as prominent spokesmen for the Círculo in El Socialista. At the other extreme within the group were the moderates led by Romero and Cano, who, with government support, advocated cooperation with the government and a program of remedial parliamentary legislation. The great bulk of the organization's membership, caught between conflicting ideologies, was influenced by each and continued to vacillate between Romero's idea of order and progress and the revolutionary militancy of the anarchists and radicals. After electing Romero to the presidency of the Círculo many joined "sociedades de resistencia " organized by La Social.

Important strikes occurred during the latter half of 1872 . The most

${ }^{26}$ El Socialista, Nos. 15, October 15, 1871; and 19, November 12, 1871.

${ }^{27}$ El Socialista, No. 15, September 29, 1872.

${ }^{28}$ El Socialista, No. 37, November 23, 1873. 
serious one began on August 1 in the future trouble spot, the Englishowned mine Real del Monte, near Pachuca in the state of Hildago.28 The strike was provoked by a reduction in the workers' salary from two pesos to one peso per day that had gone into effect on July 15. The Círculo became involved, at least to the extent of offering moral support and assisting the strikers. The miners demanded the reinstitution of the original salary and, in addition, a reduction in working time from eighteen to sixteen hours per day.

Although the miners were dealt with severely and their strike objectives were not fully realized, their action set off a wave of protests in the regular press of Mexico City, which demanded that the Lerdo government take vigorous action against the "new and dangerous tactic of striking." Encouraged by limited success and by inflammatory articles in El Socialista, the miners formed a " resistance society." The government reacted by secretly deporting many of the strike leaders to Campeche and Yucatán. ${ }^{30}$

The workers at La Fama Montañesa near Mexico City suffered a similar fate; after a short strike that began on September 9, they were forced back to work by the army. At that time they were apparently unable to form any permanent body for "the protection of their interests" vis-a-vis the employers. ${ }^{31}$

During the period 1872-1875, with the Círculo for the most part, in the hands of Romero and the moderates, the anarchists temporarily disbanded $L a$ Social and maneuvered themselves once again into a position of dominance in the Sociedad Artística Industrial. ${ }^{32}$ Their apparent motive was to obtain an established and legitimate base within the labor movement from which they could operate.

Using the Sociedad, the Círculo, and several mutualist societies in their campaign, the anarchists strived to create a viable cooperativist movement. Velatti described their vision this way; “. . . we, poor dreamers for the happiness and material benefit of our brothers, do not doubt for a moment that the cooperative system of consumption will be better for them than the mutualist system. It will save them from the charity ward, from misery, from the venomous claw of hunger, and

${ }^{29}$ El Socialista, No. 7, August 4, 1872.

${ }^{30}$ El Socialista, No. 9, August 18, 1872; also see the articles by Ricardo Velatti in El Obrero Internacional, Nos. 10, November 3, 1874; and 14, December 1, 1874.

${ }^{31}$ El Obrero Internacional, Nos. 6, October 6, 1874; and 7, October 13, 1874.

32 El Obrero Internacional, No. 1, August 31, 1874. 
from the greed of capitalism, that today, more than ever before, is the greatest and most fierce enemy of labor." ${ }^{3}$

Perhaps the best available example of how the Mexican anarchists propagated their ideology and what they meant by "cooperativism" was provided by José María González when he argued for the idea in 1876:

When they (the Producers) have collected enough money they should start cooperative stores stocked with ... (their products). The other associations will then purchase the goods sold in the stores. In this manner the worker becomes independent of the capitalist and the value returned to him for his labor is increased.

They will then use their increasing funds to purchase land and settle colonies and a sense of patriotism will develop for the colony to which one is born. When prosperity smiles on the colony, there will be schools-for the instruction and education of both the children and adults-which will be perfectly attended and produce a higher moral code that will ... eliminate the vices that infect other societies. By this means one creates a society with no need of government with its imperfect schools, its manner of calling to the fore the violent emotions and wars caused by hunger, and which is the reason for the multitudes of criminals to be found in our jails. ${ }^{34}$

In order to escape the "hunger and misery encumbent upon the laboring class within the capitalist system," the anarchists were urging the workers to form a system of communities consistent with many of the workers' recent countryside background. That is, communities which would be economically self sufficient and capable of existing separately from, while geo-politically still within, a capitalist society. ${ }^{35}$ Government was seen by the anarchists as the stumbling-block in achieving societal perfection, and González saw collectivism as a means of eliminating the need for government and its accompanying evils.

The anarchist campaign for a collectivist society was sustained and vigorous during the 1870 's. It enjoyed at least some success. In 1872 at least one mutualist society, the Sociedad Progresista de Carpinteros, was converted by Velatti to cooperativism. About this time the Círculo

\footnotetext{
s3 Ibid.

${ }^{34}$ González, "Las Sociedades Mutualistas," El Hijo, No. 16, August 6, 1876.

${ }_{35}$ For a discussion of the agrarian aspects of this question see Hart, "Agrarian Precursors of the Mexican Revolution: The Development of an Ideology," The Americas, October 1972. This is what happened between 1934 and 1939 in the Levant and Old Aragon in Spain; see Hugh Thomas, "Agrarian Anarchist Collectives in the Spanish Civil War," in Martin Gilbert, editor, A Century of Conflict, 1850-1950: Essays for A. J. P. Taylor (Atheneum Publishers, New York, 1967), 245-263.
} 
attempted to begin cooperative workshops. This was done after exhortations by Juan de Mata Rivera and the reading out loud to the Círculo of a book espousing the virtues of collectivism. ${ }^{38}$

During the meeting of September 16, 1873, Velatti in his keynote address encouraged the Círculo to adopt cooperativism:

... No more cofradias, we are forming cooperatives for consumption, which will also have social and international functions. Never doubt it, they will lift us up and cause the growth of (cooperative) workshops, factories, mills, and railroads.

Velatti cleared up any misconceptions regarding why he felt cooperativism was a necessary replacement for capitalism:

.. . Capital, here we have the terrible enemy of the worker. The ruined ambitions, the tears, and the misery at your doorstep are not enough. Were it not for (the power of) the strike they would reduce salaries that are already too low. All over the valley (of Mexico) we see continuous strikes by workers, in different kinds of factories, who prefer a thousand times the suffering, (resulting from the strikes) to that which they have to endure while they continue to increase the wealth of their bosses, who, being despots and tyrants, act like petty kings in order to fill their coffers from the sweat of those who have to work in order to take care of the basic necessities of life..$^{37}$

The anarchists' campaign for cooperativism was conducted by organizing new urban labor associations, by continuing activities in previously organized groups, and through a steady flow of articles in workingclass newspapers such as El Hijo del Trabajo and El Socialista. Their greatest success came in 1876. A working-class neighborhood in Mexico City, the Colonia Obrera de Buenavista, was organized into a cooperative called the Asociación Cooperativa de Consumo de Obreros Colonos. José Muñuzuri, a member of La Social and the editor of El Hijo del Trabajo, was elected president. He commemorated the event in an editorial:

This group of men have united, using the most powerful weapon of a free people-association. They have said in unison-War on usury and misery! War on the miserable exploitation by a few!

... Only through the union of the working people, of the productive

${ }^{36}$ Rosendo Rojas Coria, Tratado de Cooperativismo Mexicano (Fondo de Cultura Económica, México, D.F., 1952), 186 and 125. The book was Fernando Garrido's Historia de las Asociaciones Obreras en Europa (Barcelona, May 28, 1864,) available in the Biblioteca Arus, Barcelona. Garrido was one of Spain's leading "libertarian socialist" intellectuals at the time.

${ }^{37}$ El Socialista, No. 38, September 21, 1873. 
people, those that have always been the sport of the rulers, is happiness possible. No more misery, an end to poor conditions, unity in order to be strong, unity for happiness, unity in order to remedy and correct abuses and to abolish crime. ${ }^{88}$

The continuing adverse working conditions contributed to the growth of both the labor movement, anarchism, and radical ideas. By 1874 the Círculo's membership was estimated at 8,000. ${ }^{38}$ It continued to grow, but its moderate leadership left it vulnerable to criticism. By 1876 the anarchist members of the Círculo had begun to make gains against the moderates. They objected to the acceptance of money from the government; to the formation of several " company unions" sponsored by factory owners in conjunction with the Círculo leadership; and to the Circulo's refusal, through decisions of the leadership clique, to support a serious strike at La Fama Montañesa factory. They also strongly attacked El Socialista for its relatively conservative editorial stance. ${ }^{40}$

During the early 1870 's, it was the growing conviction of virtually every prominent member of the urban labor movement that the longheld belief in the efficacy of a nationwide organization was justified, and by the end of 1875 steps were being taken to convene a national workers' congress. ${ }^{41}$ The anarchists had long supported this idea, and Villanueva had worked toward it as early as 1869. Mata Rivera, editor of El Socialista and friend of Rhodakanaty, was the man who presented the formal proposal for a national workers' congress to the special junta designated by the Círculo to consider the project. ${ }^{42}$ The junta apparently completed its work successfully, because the Congreso General Obrero de la República Mexicana, with Círculo support, met for the first time on March 5, 1876, in the salon of the Sociedad Artística Industrial with 35 of the approximately 73 delegates present. ${ }^{43}$

The first Congreso spent most of its time with the tedious details of organizing special committees and electing officers. It is interesting to note that, although the Círculo supported the Congreso, no members of

\footnotetext{
38 José Muñuzuri, article in El Hijo, No. 18, August 20, 1876.

${ }^{39}$ El Obrero Internacional, No. 9, October 27, 1874.

40 El Hijo, Nos. 3, May 1, 1876; 6, May 22, 1876; 11, July 2. 1876; and 19, August 27,
} 1876.

${ }^{41}$ The first recorded reference to a national workers' congress can be found in "Los Obreros de San Luis Potosí," El Socialista, No. 15, October 15, 1871. This need was discussed repeatedly in the pages of El Hijo in 1876, El Obrero Internacional in 1874 and in El Socialista during the period from late in 1875 throughout 1876.

42 El Socialista, No. 165, February 27, 1876.

${ }^{43}$ El Socialista, No. 166, March 5, 1876. 
its conservative faction were elected to the directorate of the congress. Nor were any elected from the anarchist faction, which was represented by delegates from several groups including the Sociedad Artística Industrial. $^{44}$ This was probably the result of an initial spirit of cooperation; however, since new officers were elected at the end of each month, both sides were frequently represented later. ${ }^{45}$ The manifesto of the national Congreso contained clauses which indicate the continuing spread of "libertarian socialist" ideology in Mexico. It contained calls for "social guarantees" and cooperativist enterprises ... " independent of individual and capitalist interest, in order to put an end to misery and its accompanying ills." ${ }^{46}$ These demands were made almost word for word in the rhetoric used on many occasions by Rhodakanaty, Velatti, and José María González.

La Social was reorganized on May 7, 1876. In a speech Rhodakanaty explained that this had been done to help develop cooperativist ideas, to create an international labor organization, and to fill the need for a "vanguard" revolutionary group. ${ }^{47}$ The implications for the Congreso were obvious. La Social sent a five member delegation. ${ }^{48}$

Two of the representatives sent by La Social to the Congreso were women, and Mata Rivera opposed their being seated. Although he professed the utmost regard for Rhodakanaty and La Social, he charged that admitting female delegates would violate precedent. Muñuzuri, the editor of El Hijo, which was now the official organ of the Círculo, led the debate in support of the ladies. Thus, the editor of El Socialista, who, although a friend of Rhodakanaty, also had close ties with the moderate Romero faction, debated the editor of El Hijo, who was the voice of the more militant elements, regarding the seating of lady delegates. However, the issues separating them were more inclusive. El Hijo had been critical of the moderates in the Círculo and the directorate of El Socialista because of their willingness to take part in national politics and their failure to take a more favorable stance regarding the organization of a cooperativist movement. The assembly supported Muñuzuri and for the first time in the history of the Mexican labor movement female delegates were seated. ${ }^{49}$ No doubt passions generated during the

\footnotetext{
${ }^{44}$ El Socialista, No. 168, March 21, 1876.

${ }^{45}$ For example see El Socialista, No. 180, June 11, 1876.

46 "Manifesto," El Socialista, No. 173, April 23, 1876.

${ }^{4} \mathrm{El}$ Hijo, No. 4, May 9, 1876.

48 El Socialista, No. 175, May 7, 1876; and El Hijo, No. 4, May 9, 1876.

${ }^{49}$ El Hijo, No. 6, May 22, 1876. Also see the article by Juana la Progresista.
} 
rivalries of several years affected the decision of the Congreso as much as did any ethical consideration of women's rights. This event, in its own right, however, did have lasting consequences. Women soon became important in the affairs of the Congreso, and Carmen Huerta was elected its president in 1879 and again in $1880.0^{\circ 0}$ In addition, the anarchists had served notice that they were a force to be reckoned with.

During 1876 the anarchists continued to gain strength in the congress. By June, only a month after the debate over lady delegates, the representation of La Social in the Congreso had been increased with the appearance of Rhodakanaty, Juan Villareal, Evarista Mesa, and Colin y López. ${ }^{51}$ These men represented a formidable contingent in the congress, since they were well known in the labor movement as persuasive agents for their cause.

In 1876 there were at least four major divisions within the labor movement which were much more complex than the obvious conflict between the moderates and the anarchists. The primary cause of these divisions was a three-way civil war between elements supporting the national presidential aspirations of Lerdo de Tejada, Porfirio Díaz, and José María Iglesias. The anarchists were opposed to working-class participation in the struggle because they viewed it as a clash between mere individuals vieing for power. They complained that the fighting was destroying the national economy and costing the lives of the workers and campesinos, who, they said, did all of the fighting and had nothing to gain regardless of the outcome. ${ }^{52}$

The leading moderates in the Circulo continued to support Lerdo during the struggle; other members favored Iglesias because of the legal technicalities that legitimized his candidacy. ${ }^{53}$ Díaz enjoyed the greatest support because of his outstanding record as an officer in the Liberal army of Juárez and because of the rather vague promises regarding social reform he had made to the workers in his plan of Tuxtepec. ${ }^{54}$

The situation was complicated in June when Lerdo's supporters, including the staff of El Socialista, endorsed Lerdo and withdrew from the Círculo because that group was already dominated by Díaz sympa-

${ }^{50} \mathrm{El} \mathrm{Hijo,} \mathrm{Nos.} \mathrm{178,} \mathrm{December} \mathrm{20,} \mathrm{1879;} \mathrm{and} \mathrm{199,} \mathrm{May} \mathrm{16,} 1880$.

${ }^{51}$ El Socialista, No. 180, June 11, 1876.

52 For example see the articles by Juan Villareal and José María González in El Hijo, No. 29, December 24, 1876.

${ }^{53}$ El Socialista, No. 182, June 25, 1876.

${ }^{54}$ See the numerous articles extolling the virtues of Díaz and the plan of Tuxtepec in El Hijo during 1876. 
thizers. ${ }^{55}$ This event meant the eventual death of the original Círculo. Between 1876 and 1878 the anarchists were joined by other groups of dissenters in a boycott of the Círculo because of its pro-Díaz sympathies. After their departure, the ranks of the Circulo were further decimated by the withdrawal of many former Díaz enthusiasts. Initially they had been attracted to the new president by his promises of progressive reforms, but they were quickly disillusioned by his closing of El Hijo for two months in $1876 . .^{58}$ In 1877 and 1878 Díaz followed this offense by allowing the controversial expulsion of some 600 campesino families from the Rancbo de San Vicente in the state of San Luís Potosí by armed men from the Hacienda de las Bocas. This was done in spite of vehement and sustained protests from the working-class newspapers in Mexico City. ${ }^{57}$ These actions, combined with his failure to make in El Hijo, La Internacional, and El Socialista throughout the two year period.

good on his promises to help the workers, resulted in a drastic reduction in the number of Díaz supporters in the labor movement. By 1878 the Círculo had become a mere skeleton organization with few, if any, active members. ${ }^{58}$

José María González led an attack on the Círculo's pro-Díaz leadership by accusing it of accepting gifts, money, and positions from the government. González was an outspoken anarchist writer whose articles appeared regularly for years in El Hijo. Francisco de Paula González, an outspoken cooperativist and new editor of $E l H i j o$, was the other principal leader of the dissidents. His newspaper was instrumental as the primary propaganda vehicle for the publication of charges against the Circulo. Both men supported the formation of a rival labor organization in 1878, the Zacatecas Gran Círculo de Obreros. ${ }^{58}$

As soon as the new group established itself in Zacatecas, it began to receive messages of support. One of the more important was an endorsement of their organization by the regional strong man in Zacatecas, General Trinidad García de la Cadena, who offered his protection. Another manifesto expressing support came from the workers' associations of Tlalpan, San Ildefonso, Contreras, Rio Hondo, and La Colmena. ${ }^{80}$

${ }^{35}$ El Socialista, No. 182, June 25, 1876.

${ }^{56}$ El Hijo, No. 27, December 14, 1876.

${ }^{37}$ See El Hijo, Nos. 71, December 2, 1877; 72, December 9, 1877; and countless articles

${ }^{58}$ El Hijo, Nos. 80. February 3, 1878; and 82, February 17, 1878.

${ }^{59}$ El Hijo, Nos. 141, April 6, 1879; and 142, April 13, 1879.

${ }^{60} \mathrm{Ibid}$. 
The Zacatecas insurgents next formed a branch in Mexico City, which was commonly referred to as the Primer Sucursal. The anarchists' domination of both the Congreso and the new Sucursal was illustrated by the election of La Social members to the two highest offices in each organization. In the Congreso, Carmen Huerta was elected president; and José María González, first secretary. In the new Sucursal, Juan B. Villareal, a Spanish cooperativist, was elected president; and Felix Riquelme, first secretary. At this point the propagation of anarchist ideology to the Mexican working class reached a high point for the nineteenth century.

The remaining leaders of the almost moribund Círculo in Mexico City tried to discredit the Zacatecans by accusing them, with a degree of accuracy, of being partisan supporters of García de la Cadena for the presidency of the republic, but their charges fell upon deaf ears. ${ }^{61}$ Most of the moderates were supporters of Cadena, but the militants of $\mathrm{La}$ Social and El Hijo, who now dominated the Congreso and the Sucursal in Mexico City, resisted them and issued a proclamation protesting the involvement of some members of the Zacatecas group in the political campaign. El Hijo went so far as to attack Cadena for his political ambitions, in spite of his instrumental role previously as the savior of the Zacatecas Círculo when it had been faced with the opposition of President Díaz. ${ }^{82}$

Thus, the ascension to power of Porfirio Díaz had resulted in an alliance of such anti-Díaz labor groups as the anarchists, the former Lerdo supporters who would not accept the new president, and most of the moderates who had initially rallied behind Díaz but soon became disenchanted and left him. These groups came together in order to form the Círculo of Zacatecas as an alternative to the Díaz-dominated Círculo in Mexico City.

During the presidential campaign of 1880 the Círculo in Zacatecas declared its support for Cadena. The anarchists opposed this move, as did most of the members of the Congreso. But at this time there was increased unity in the urban labor movement, and the groups did not break up over the issue. There were two important reasons for this stability. The political advocacy was in behalf of an opponent of a mutually hated government; and the candidate, Cadena, was well liked by the working-class movement and even by the anarchists who, al-

61 El Hijo, No. 199, May 16, 1880.

${ }^{62}$ El Hijo, Nos. 196, April 25, 1880; and 199, May 16, 1880. 
though they disapproved of anyone's candidacy, respected him because of his radical and pro-working-class political position. ${ }^{88}$

The depth of the anarchists' disagreement with those who supported political involvement on the part of the Círculo of Zacatecas, the Congreso, or the Sucursal and the extent of their influence became evident during a rally that took place on December 14, 1879, at Columbus Park in Mexico City. The Congreso had called for a mass meeting to install its newly elected monthly officers, of whom José María González (vice president) and José Rico (first secretary) were members of La Social. Some 5,000 persons gathered replete with several hundred red and black flags, many of which bore the inscription "La Social, Liga Internacional del Jura." In front of the speaker's platform was a large black banner bearing the inscription "La Social, Gran Liga Internacional." The meeting quickly turned into a debate among the leading figures over the issue of whether or not it was possible for "socialists" to take part in the activities of an organization such as the Congreso if it became active in politics. The speakers generally agreed on one point: ". . . that the separation of La Social and the Congreso would be prejudicial to the cause of the Mexican proletariat." ${ }^{84}$

Because the delegates to the Congreso constituted a strong link with Mexican urban labor, the anarchists considered them to be an important vehicle for the continued development of their ideology. Also, because a majority of the group supported the anarchist position of non-political involvement, the La Social membership decided that its continued inclusion in the organization was worthwhile. They may also have felt that political conditions made it imperative for them to be as closely involved as possible with the Congreso in case pro-Díaz elements tried to infiltrate and dominate the organization.

The membership of the Congreso supported the anarchists between 1879 and 1882 in part because of the chaos and despair that had been brought about by the civil war of 1876 and because some of them believed that the oppressive and disappointing policies of the Diaz regime had fulfilled the anarchists' dire prophesies regarding the ultimately evil nature of the national government. Another reason why the labor move-

${ }^{63} \mathrm{lbid}$. Cadena had a long and impressive record of support for both the urban labor and agrarian movements. For details see Trinidad García de la Cadena, General de la Brigada, Expediente 15-395, Archivo Histórico de la Defensa Nacional (AHDN), México D. F.

${ }^{64}$ El Socialista, No. 97, December 18, 1879; El Hijo, Nos. 177, December 14, 1879; and 178 , December 20, 1879. 
ment accepted not only anarchist ideas, which had always influenced it, but also anarchist domination of the movement itself was the anarchists' increased strength in the period 1876-1882. During 1877 and 1878, La Social had continued to organize; and it reached the peak of its strength in 1879-1882. In 1878 the organization claimed to have 62 regional sections located in, and propagandizing in, urban centers throughout the country. ${ }^{85}$ The anarchists had become, by far, the strongest force in Mexican labor. In the early 1880's they dominated the Congreso which, in 1882, after its reorganization and official entry into the European based anarchist International Workingmens Association, claimed 100 affiliated societies and a total enrolled membership of $50,236^{\circ 6}$

The anarchists had succeeded in spreading their ideology because of desperate socio-political conditions and because of a persistent and intensive proselytizing effort by grass roots organizers. One of their chief weapons was the working class press. Besides their continuing efforts in newspapers like $E l$ Hijo and El Socialista; La Social published a newspaper, La Internacional, during the last six months of 1878 . It was edited by Francisco Zalacosta and carried articles written by members such as Rhodakanaty, Riquelme, Rico, and Francisco Tijera. The paper was an articulate spokesman for the program of La Social and the Mexican anarchist movement. Each issue carried their twelve-point program which called for, among other things, "a universal social republic, autonomous government by the municipality, feminine rights, workers' falanges, abolition of salaries (workers' control), and equality of property holdings."

An excerpt from an article written by Rhodakanaty in 1878 describes not only his philosophical concept of government and his assessment of contemporary conditions in Mexico, but also reflected a developing ideology, the heritage of which would influence Mexican urban labor revolutionaries of the early 20 th century. His views were representative of the general attitude expressed by La Social members between 1865 and 1882:

... The power of government and democratic liberties are not compatible because all forms of government necessarily kill the idea of perfect equality. ... The republic, in order to develop its democratic institutions, is in no need of this tyranny called government. The

${ }^{65}$ La Internacional, Nos. 8, August 25, 1878; and 14, October 6, 1878.

${ }^{68}$ El Socialista, No. 34, September 26, 1882. 
organization of the economy into free municipalities, unique and sovereign, is enough for the restructuring of the social mechanism. ${ }^{67}$

While the anarchists were strong, they openly talked of a violent "struggle against the enemies of humanity." Even though virtually all of the leading anarchists were artisans, they always tried to identify themselves with, and to act as "the official spokesmen" of the lowest and most oppressed elements of the people. ${ }^{68}$ They were consistent in their opposition to government and in their call for a re-organization of political and economic power, through the development of a cooperativist social order. But their early successes were soon replaced by repression and near disappearance during the late 1880's and 1890's. It was not until the early twentieth century that the nineteenth-century anarchist labor tradition in Mexico would again make itself felt.

Urban industry in Mexico during the 1880's was still too weak to give rise to a sufficiently powerful labor movement capable of resisting a Díaz regime that was consolidating its power and preparing to move against dissidents. The Rurales, who had been decimated during the civil war of 1876, were rebuilt by Díaz in the late 1870's. During the same period the army was reconstructed. Díaz at the same time created a wide following within the national community at large and even enjoyed limited support within some elements of the working class. With this base the dictator was in a solid position to confront dissidents.

Several anarchist militants and supporters were killed by government troops. Zalacosta was chased across the Mexican countryside before being captured and shot at Querétaro in 1880. In the next few years several agrarian leaders affiliated with La Social and the Congreso were arrested and exiled to the northern frontier. A series of anarchist inspired agrarian uprisings and labor strikes were violently suppressed between 1878 and 1884 , when they were finally snuffed out. Finally, García de la Cadena, the most consistent supporter of the urban labor movement, was killed in 1886 by his army captors in Zacatecas under the conditions of the Ley de Fuga. ${ }^{69}$ The working-class press was

67 Rhodakanty, "El Estado es el Padrastro del Pueblo," La Internacional, No. 7, August 18, 1878.

${ }^{68}$ For example see any issue of La Internacional.

${ }^{69}$ General Carlos Lueso, a ministerio de Guerra y Marina, Zacatecas, Octubre 25 , 1886, Expediente 15-395, Documento 220, (AHDN); Noviembre 11, 1886, Expediente 218, ibid.; Documentos 204, Octubre 19, 1886; 214, Octobre 20, 1886; and 219, Noviembre 16, 1886, ibid. For a newspaper account see El Siglo XIX, (México D. F.), November 3, 1886. The practice of killing prsioners became common during the Porfiriato and was referred to as the Ley de Fuga-" killed while trying to escape." 
shackled..$^{70}$ In 1881 the Congreso invited trouble with Díaz by affiliating with the anarchist international. The Mexicans were represented at the 1881 London convention of the international by an American delegate from Boston named Nathan Ganz. ${ }^{71}$

By 1883 the Sucursal and La Social had vanished. The Gran Círculo of Zacatecas suffered the same fate after García de la Cadena was killed. That they were dispersed by the government is clear. Strikes, while frequent, were rarely tolerated, and after 1884 attempted strikes in the textile mills of central Mexico were, routinely, broken up by troops or police. The Congreso, with the bulk of its original revolutionaries removed, and at the sufferance of the government continued to proselytize on behalf of cooperativism and to organize workers until the mid1890's. The official newspaper of the Congreso during this period, La Convención Radical, betrayed its ideological commitment with observations such as "Paris proclaimed the Commune, this is ... the municipio libre, la autonomía municipal." "2 Pedro Ordóñez, president of the Congreso and vice president of La Convención, pursued the objective of autonomía municipal by successfully running for election as a regidor of Mexico City, the one level of government that the anarchists believed in. ${ }^{73}$ In the late 1880 's the city and national governments cooperated with the Congreso, now led by Ordóñez and Dolores Huerta, in a few experimental cooperatives. ${ }^{74}$ The government soon lost interest however, and the projects died for a lack of funds. ${ }^{75}$ During the late 1880's and 1890 's new labor groups appeared. Some of them operated under the aegis of the regime, accepted cash subsidies and meeting salons from Díaz, and openly supported him, as did the Congreso, in his campaigns for reelection.

${ }^{70}$ The working class press did not submit without protest. For example see Luigi, "La Revolución es Necessaria," El Hijo, No. 179, December 28, 1879; and El Hijo, No. 241, March 6, 1881.

${ }^{71}$ Nathan Ganz, "What We Will and What We Will Nor," and "War Against the Authorities by Various Methods and Means," El Socialista, No. 1, January 10, 1881. See also, Valadés, Mexico City, to Nettlau, April 26, 1924, Nettlau Archive, Instituut Internationaal voor Sociale Geschiedenis. For a description of Ganz' antics at the convention see George Woodcock, Anarchism; A History of Libertarian Ideas and Movements (The World Publishing Company, Cleveland, 1962), 258.

${ }^{2}$ Andrés Díaz Millán, editorial in La Convención Radical, (México D.F.), No. 35, January 9, 1887.

${ }^{73}$ For a brief biography of Ordóñez see El Socialista, No. 24, June 30, 1881.

${ }^{74}$ La Convención Radical, No. 35, January 9, 1887; and No. 36, January 16, 1887.

${ }^{75}$ Mexico, Memoria de Fomento, Colonización E Industria de la República Mexicana, 1883-1885 (México D. F., Tip. de la Secretaría de Fomento, 1887), 195-203; and Mexico, Memoria de Fomento, Colonización E Industria de la República Mexicana, 1892-1896 (México D.F., Tip. de la secretaría de Fomento, 1897), 13-16. 
But the ideological heritage developed by the nineteenth-century labor movement lingered on. Despite serious setbacks, the radical labor activists and anarchists did not abandon their efforts within the Mexican labor movement. Organizing continued during the 1880's and 1890's and wildcat strikes in $1885,1888,1889,1892$ and the severe strikes of 1895 bore evidence of these activities, especially in the textile mills. ${ }^{78}$ But it was not until the early twentieth century with the strikes at Rio Blanco, led by the Gran Círculo de Obreros Libres of Orizaba, the confrontation at Cananea, and the emergence of the Flores Magonistas that Mexican labor returned to the militant-revolutionary-and anarchist stance that was inherited from the precursors of the nineteenth century.

The working class ideology developed during the struggles of the nineteenth century foreshadowed most of the concepts espoused by the anarco-syndicalist Casa del Obrero Mundial during the Revolution of $1910 .{ }^{77}$ The Casa program called for "sociedades de resistencia" to better the living conditions of the workers, to protect them from the capitalists by forming cooperatives and by means of the general strike, eventually to control the factories and means of production, and to affiliate the Mexican labor movement with the "anti-authoritarian" International Workingmens Association and IWW..$^{78}$ The ideas of the Casa were more syndicalist than its nineteenth-century predecessors, but this was the logical product of an increasingly urbanized and industrialized society. The leaders of the urban labor movement during the intense struggles before and throughout the Porfiriato made significant contributions to the developing ideology. An examination of their ideas and history contributes to a more complete understanding of the origins and nature of the Mexican Revolution.

\section{University of Houston}

JoHN M. HaRT

Houston, Texas

${ }^{76}$ González Navarro, Las Huelgas Textiles en el Porfiriato (Editorial José M. Cajica Jr., Puebla, 1970), 29-44. For events in 1906-1907 see Rodney Anderson, "The Mexican Textile Labor Movement, 1906-1907: An Analysis of Labor Crisis," Ph.D. dissertation, The American University, Washington, D. C., June 1968.

${ }^{77}$ An essay by a principal leader of the Casa del Obrero Mundial that demonstrated appreciation of the earlier accomplishments of Mexican labor was Jacinto Huitron, Orígenes é Historia del Movimento Obrero en México, unpublished manuscript.

78 For an examination of the Casa del Obrero Mundial see Rosendo Salazar, Las Pugnas de la Gleba (2 vols., Editorial Avante, México D. F., 1917), and Fernando Córdova Pérez, El Movimiento Anarquista en México (1911-1921), Licenciado Thesis, Universidad Nacional Autónoma de México, México, D. F., 1971. 